\title{
Periapical status and prevalence of apical periodontitis in patients with type 2
}

\section{Diabetes mellitus}

\author{
Condição periapical e prevalência de periodontite apical em pacientes com Diabetes mellitus tipo 2 \\ Condición periapical y prevalencia de periodontitis apical en pacientes con Diabetes mellitus tipo 2
}

Received: 09/01/2021 | Reviewed: 09/09/2021 | Accept: 09/14/2021 | Published: 09/16/2021

Juliana Érnica Bernardo

ORCID: https://orcid.org/0000-0001-5406-0947 Universidade Estadual Paulista, Brazil

E-mail: julianaernica2@gmail.com

Caroline Loureiro

ORCID: https://orcid.org/0000-0002-9035-2960 Universidade Estadual Paulista, Brazil

E-mail: caroline.loureiro@unesp.br

Ana Paula Fernandes Ribeiro

ORCID: https://orcid.org/0000-0001-5313-5003 Universidade Estadual Paulista, Brazil E-mail: apf.ribeiro@unesp.br

Júlia Guerra de Andrade

ORCID: https://orcid.org/0000-0001-8167-2535 Universidade Estadual Paulista, Brazil E-mail: julia.guerra@unesp.br

Gladiston William Lobo Rodrigues

ORCID: https://orcid.org/0000-0002-1286-3984 Universidade Estadual Paulista, Brazil E-mail: gladiston.william@unesp.br Rogério de Castilho Jacinto

ORCID: https://orcid.org/0000-0002-2362-8920 Universidade Estadual Paulista, Brazil

E-mail: rogerio.castilho@unesp.br

\begin{abstract}
Diabetes mellitus (DM) is a chronic systemic disease that affects the immunoinflammatory response, leading the patient more susceptible to the development of oral diseases, such as apical periodontitis (AP). Thus, this study aimed to clinically and radiographically analyze the periapical status and prevalence of AP in diabetic patients compared to healthy patients. A total of 100 patients were selected and divided into two groups $(\mathrm{n}=50)$ : diabetic group - patients with type $2 \mathrm{DM}$, and control group - systemically healthy patients. Periapical status was analyzed by the periapical index. The quality of the root canal filling and restoration was also evaluated. Difference between the prevalence of AP among the groups were performed by using the Chi-square test or Fisher's exact test $(p<0.05)$. The total number of teeth was lower in diabetic group $(\mathrm{p}=0.049)$. Teeth without previous endodontic treatment with AP were higher in diabetic group $(p=0.006)$. However, the number of endodontically treated teeth with AP was greater in the control group $(\mathrm{p}=0.027)$. AP in teeth with previous endodontic treatment was associated with unsatisfactory root canal filling and restoration quality $(\mathrm{p}<0.01)$. The presence of pain showed significantly higher values in the diabetic group $(\mathrm{p}=$ 0.003). In conclusion, this study showed an association between the presence of AP and DM in cases of teeth without endodontic treatment. Besides, the presence of pain was significantly higher in diabetic patients. However, healthy patients showed more cases of AP in endodontically treated teeth.
\end{abstract}

Keywords: Apical periodontitis; Diabetes mellitus; Endodontics.

\section{Resumo}

O diabetes mellitus (DM) é uma doença sistêmica crônica que afeta a resposta imunoinflamatória, deixando o paciente mais suscetível ao desenvolvimento de doenças bucais, como a periodontite apical (PA). Assim, este estudo teve como objetivo analisar clínica e radiograficamente a condição periapical e a prevalência de PA em pacientes diabéticos em comparação com pacientes saudáveis. Foram selecionados 100 pacientes, divididos em dois grupos $(\mathrm{n}=$ 50): grupo diabético - pacientes com DM tipo 2 e grupo controle - pacientes sistemicamente saudáveis. A condição periapical foi analisada pelo índice periapical. A qualidade da obturação e restauração do canal radicular também foi avaliada. A diferença entre a prevalência de PA entre os grupos foi analisada por meio do teste Qui-quadrado ou teste exato de Fisher $(\mathrm{p}<0,05)$. O número total de dentes foi menor no grupo diabético $(\mathrm{p}=0,049)$. Dentes sem tratamento endodôntico prévio com PA foram maiores no grupo diabético $(\mathrm{p}=0,006)$. Porém, o número de dentes tratados 
endodonticamente com PA foi maior no grupo controle $(\mathrm{p}=0,027)$. A PA em dentes com tratamento endodôntico prévio foi associada a qualidade insatisfatória da obturação de canais radiculares e da restauração (p <0,01). A presença de dor mostrou valores significativamente maiores no grupo diabético ( $\mathrm{p}=0,003)$. Em conclusão, este estudo mostrou uma associação entre a presença de PA e DM em casos de dentes sem tratamento endodôntico. Além disso, a presença de dor foi significativamente maior nos pacientes diabéticos. No entanto, pacientes saudáveis apresentaram mais casos de PA em dentes tratados endodonticamente.

Palavras-chave: Periodontite apical; Diabetes mellitus; Endodontia.

\section{Resumen}

La diabetes mellitus (DM) es una enfermedad sistémica crónica que afecta la respuesta inmunoinflamatoria, haciendo al paciente más susceptible al desarrollo de enfermedades bucales, como la periodontitis apical (PA). Así, este estudio tuvo como objetivo analizar clínica y radiográficamente la condición periapical y la prevalencia de PA en pacientes diabéticos en comparación con pacientes sanos. Se seleccionaron cien pacientes, divididos en dos grupos $(n=50)$ : grupo diabético - pacientes con DM tipo 2 y grupo control - pacientes sistémicamente sanos. La condición periapical se analizó mediante el índice periapical. También se evaluó la calidad del relleno y la restauración del conducto radicular. La diferencia entre la prevalencia de PA entre los grupos se analizó mediante la prueba de chi-cuadrado o la prueba exacta de Fisher ( $\mathrm{p}<0,05)$. El número total de dientes fue menor en el grupo de diabéticos $(\mathrm{p}=0.049)$. Los dientes sin tratamiento endodóntico previo con PA fueron mayores en el grupo de diabéticos $(\mathrm{p}=0,006)$. Sin embargo, el número de dientes tratados endodónticamente con PA fue mayor en el grupo de control $(\mathrm{p}=0,027)$. La PA en dientes con tratamiento endodóntico previo se asoció con una mala calidad del relleno y la restauración del conducto radicular $(\mathrm{p}<0,01)$. La presencia de dolor mostró valores significativamente superiores en el grupo de diabéticos $(\mathrm{p}=0,003)$. En conclusión, este estudio mostró una asociación entre la presencia de PA y DM en casos de dientes sin tratamiento endodóntico. Además, la presencia de dolor fue significativamente mayor en los pacientes diabéticos. Sin embargo, los pacientes sanos tenían más casos de PA en dientes tratados con endodoncia.

Palabras clave: Periodontitis periapical; Diabetes mellitus; Endodoncia.

\section{Introduction}

Diabetes Mellitus (DM) is a chronic systemic disease with an increasing global prevalence and incidence. In 2019, approximately 463 million adults (20-79 years) were living with diabetes worldwide, which is expected to increase to 700 million by 2045 (International Diabetes Federation, 2019). The most frequent types of DM are characterized by the destruction of $\beta$ cells, usually leading to absolute insulin deficiency (type 1) or the combination of resistance to insulin action and an inadequate response to compensatory insulin secretion (type 2) (Zimmet, Alberti, Magliano, \& Bennett, 2016). Type 2 diabetes is the most common type of disease, accounting for $90-95 \%$ of the cases, which represents an important public health problem (American Diabetes, 2013; DeFronzo et al., 2015).

Diabetic patients are more susceptible to the development of oral diseases. The most common oral manifestations include xerostomia, candidiasis, neurosensory disorders, lichen planus, gingivitis, periodontal and periapical diseases (Lamster, Lalla, Borgnakke, \& Taylor, 2008). Several studies have shown the relationship between diabetes and endodontic infections based on the increase of the prevalence of apical periodontitis (AP) (Lopez-Lopez et al., 2011; Segura-Egea et al., 2005). Furthermore, studies suggest that the size of the periapical lesions in patients with DM is usually larger than those in healthy patients (Rudranaik, Nayak, \& Babshet, 2016), and take longer to heal after endodontic treatment, especially in subjects with high blood glucose levels (Arya et al., 2017; Ugur Aydin, Ocak, Bayrak, Goller Bulut, \& Orhan, 2021).

Apical periodontitis is characterized by inflammation and destruction of periapical tissues due to the host's defense response to the presence of microorganisms and their products (Graunaite, Lodiene, \& Maciulskiene, 2012). Diagnosis of AP is based on clinical and radiographic findings. Clinically, cold sensitivity test, palpation, percussion, and the presence of pain, edema or sinus tract could be observed. As chronic AP usually presents subjective symptoms, radiographic diagnosis becomes especially relevant (Abbott, 2004). Typically, AP appears on radiography as a radiolucent area around the apex of the infected tooth. However, early in the development of the disease, it is not always possible to radiographically detect the involvement of the periapical tissue (Huumonen \& Ørstavik, 2002). 
The periapical status could be influenced by an increase in the formation of advanced glycation end-products through protein glycation implied by hyperglycemia (Ahmed, 2005; de Morais Santos et al., 2020; Ilea et al., 2018). High blood glucose levels promote abnormal intracellular molecular events that result in an altered inflammatory response, consequently making diabetes an influencing factor in oral cavity disorders (Lopez-Lopez et al., 2011). Concomitantly, chronic AP maintains the inflammatory process that can worse diabetes by increased blood glucose levels, providing an uncontrolled diabetic state (Schulze et al. 2007). Hence, this study aimed to clinically and radiographically analyze the periapical status and prevalence of AP in diabetic patients and healthy patients.

\section{Methodology}

The present cross-sectional study used images from 100 patients aged between 50 and 70 years who sought dental care at the Araçatuba School of Dentistry. All patients were informed about the research and signed an informed consent form. This study was submitted and approved by the Research Ethics Committee of the Araçatuba School of Dentistry - UNESP (CAAE: 90760118.9.0000.5420).

Glycated hemoglobin (HbA1c) was recorded on the day of treatment and according to the status of metabolic control (American Association of Clinical Endocrinologists Board of \& American College of Endocrinologists Board of, 2010). Then, the selected patients were divided into two groups: diabetic group - patients with type DM 2 with HbA1c $\geq 6.5 \%(\mathrm{n}=50)$ and control group - systemically healthy patients $(n=50)$. Patients with severe periodontal disease, smokers, pregnant women, or systemic disorders other than DM or controlled arterial hypertension were excluded from the study.

Digital panoramic and periapical radiographs of all patients were requested. Each radiography was analyzed by two specialists previously calibrated. Kappa coefficient was performed to analyze the agreement between the two evaluators.

Except for third molars, all teeth were included in the research. The following characteristics were observed: age, gender, dental condition, presence of symptoms such as pain, cold sensitivity test, sensitivity to percussion, pain on palpation, presence of sinus tract, and edema.

A form was created with the following information: (1) Total number of teeth; (2) Number of teeth with AP that had no endodontic treatment; (3) Number of teeth with root canal filling, and (4) Number of teeth with AP and root canal filling (Lopez-Lopez et al., 2011). The quality of the root canal filling and restoration were also evaluated, being considered satisfactory or unsatisfactory according to the clinical and radiographic characteristics. In addition to the analysis of patient groups, individual analyzes of teeth with endodontic involvement were performed. From the Periapical Index (PAI), the periapical condition was analyzed and considered healthy when the periodontal ligament was intact (PAI $\leq 3)$, or altered when it was possible to detect any discernible apical radiolucency (PAI > 3) (Orstavik, Kerekes, \& Eriksen, 1986).

The data collected were tabulated and statistically analyzed by using Sigma Plot 12.0 (Systat Software Inc, San Jose, USA). Differences between the prevalence of AP among the diabetic group and the control group were performed by using the Chi-square test or Fisher's exact test at a $5 \%$ significance level $(\mathrm{p}<0.05)$.

\section{Results}

The mean age of the patients was $59.7 \pm 8.9$ in the diabetic group and $56.1 \pm 7.0$ in the control group. The frequency of male and female gender in the diabetic group was 29 and 21, and in the control group 23 and 27, respectively. There was no statistically significant difference between genders and the presence of DM $(\mathrm{p}=0.317)$. In the diabetic group, it was not possible to dissociate the disease from arterial hypertension, thus 32 patients had DM associated with controlled arterial hypertension (64\%), while 18 patients had only DM (36\%). 
Table 1. Total number of teeth, root canal fillings, prevalence of apical periodontitis (AP), and clinical findings in the diabetic group and control group.

\begin{tabular}{lccc}
\hline & $\begin{array}{c}\text { Diabetic } \\
\text { group }\end{array}$ & $\begin{array}{c}\text { Control } \\
\text { group }\end{array}$ & $\boldsymbol{p}$-value \\
\hline Total number of teeth & 907 & 1031 & $0.049^{*}$ \\
With AP & 55 & 45 & 0.487 \\
Without AP & 852 & 986 & $0.044^{*}$ \\
\hline Endodontically treated teeth & 69 & 116 & 0.069 \\
With AP & 10 & 25 & $0.027^{*}$ \\
Without AP & 59 & 91 & 0.091 \\
\hline Adequate root canal filling & 53 & 84 & 0.069 \\
With AP & 6 & 12 & $0.018^{*}$ \\
Without AP & 47 & 72 & $<0.001$ \\
\hline Adequate root canal filling and restoration & 41 & 49 & 0.498 \\
With AP & 2 & 7 & 0.121 \\
Without AP & 39 & 42 & 0.704 \\
\hline Edema & 2 & 5 & 0.594 \\
\hline Sinus tract & 1 & 1 & 0.557 \\
\hline Pain & 24 & 10 & $0.003^{*}$ \\
\hline
\end{tabular}

AP: discernible apical radiolucency $(\mathrm{PAI}>3) ;{ }^{*}$ significant difference between groups. Search: Authors (2021).

Table 1 shows the statistical difference in the total number of teeth between the groups. Significant differences were found in the total number of teeth $(\mathrm{p}=0.049)$, with higher values in the diabetic group than in the control group. The total number of teeth without AP was higher in the control group ( $\mathrm{p}=0.044)$, whereas the total number of teeth with AP did not differ between groups $(\mathrm{p}=0.487)$. Generally, there were no statistical differences between the groups in relation to the total number of endodontically treated teeth $(\mathrm{p}=0.069)$. The presence of AP associated with previous endodontic treatment was greater in the control group $(\mathrm{p}=0.027)$. However, the number of endodontically treated teeth without AP showed no statistical difference $(\mathrm{p}=0.091)$.

Endodontic treatment quality was also observed, the total number of teeth with adequate root canal filling and both adequate root canal filling and restoration were not statistically different. However, the number of teeth with an adequate root canal filling with AP $(\mathrm{p}=0.018)$ and without AP $(\mathrm{p}<0.001)$ were higher in the control group than in the diabetic group. Signs and symptoms such as edema, sinus tract, and pain were analyzed. Only the presence of pain shows significantly higher values in the diabetic group $(\mathrm{p}=0,003)$ (Table 1$)$.

Table 2. Prevalence of teeth with apical periodontitis (AP) and teeth with previous root canal treatment (RCT) with AP in both groups.

\begin{tabular}{lccc}
\hline & AP & RCT + AP & Total number of AP \\
\hline Diabetic group & 45 & 10 & 55 \\
\hline Control group & 20 & 25 & 45 \\
\hline $\boldsymbol{p}$-value & $0.006^{*}$ & $0.027^{*}$ & 0.487 \\
\hline
\end{tabular}

AP: discernible apical radiolucency (PAI > 3); * significant difference between groups. Search: Authors (2021).

In general, Table 2 shows the prevalence of AP in both groups. When the total number of teeth with AP was analyzed, 
there was no significant difference. However, there was a statistical difference when individually analyzing the number of teeth (without previous endodontic treatment) with AP $(\mathrm{p}=0.006)$ and $\mathrm{RCT}$ (root canal treatment) $\mathrm{AP}(\mathrm{p}=0.027)$ between the groups.

Figure 1. Quality of root canal filling and restoration associated with the prevalence of apical periodontitis (AP).

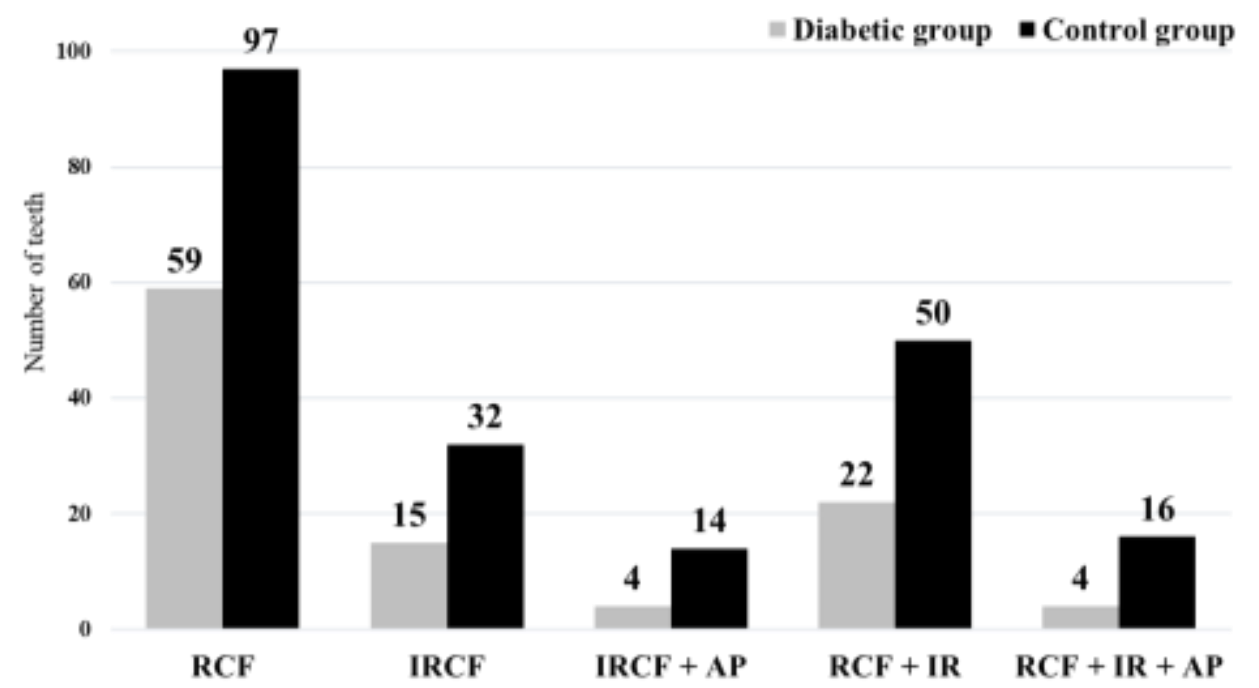

RCF: root canal filling; IRCF: inadequate root canal filling; AP: apical periodontitis; IR: inadequate restoration. Search: Authors (2021).

Figure 1 shows the number of root canal treatments according to filling quality (adequate/inadequate) and coronary restoration quality, associated or not with the presence of AP. In the control group, the presence of AP in teeth with previous endodontic treatment was associated with the quality of root canal fillings $(p=0.001)$ and restorations $(p=0.010)$.

\section{Discussion}

The present study investigated the relationship between DM and the prevalence of AP compared to healthy patients. The presence of AP was statistically associated with diabetic patients in cases of teeth without previous endodontic treatment. While in endodontically treated teeth, there was a greater presence of AP in the control group. In addition, the quality of root canal filling and coronary restoration was associated with the presence of AP in the control group.

The increased prevalence of AP has been associated with diabetic patients when compared to healthy individuals (Bender, Seltzer, \& Freedland, 1963; Falk, Hugoson, \& Thorstensson, 1989; Lopez-Lopez et al., 2011; Marotta et al., 2012; Segura-Egea et al., 2005). On the other hand, other studies did not find a significant association between diabetes and AP (Britto, Katz, Guelmann, \& Heft, 2003; Correia-Sousa, Madureira, Carvalho, Teles, \& Pina-Vaz, 2015; Smadi, 2017). Our results showed a significant increase in AP in the diabetic group associated with teeth without endodontic treatment. However, when the teeth with and without endodontic treatment associated with AP were analyzed, this difference was not significant.

The failure of endodontic treatment could be noticed by the presence of AP in endodontically treated teeth in both groups, with a statistical difference in the control group. Although this finding does not agree with studies that showed the negative influence of DM on the outcome of endodontic treatment (Cabanillas-Balsera et al., 2019; Doyle, Hodges, Pesun, Baisden, \& Bowles, 2007; Jakovljevic \& Duncan, 2020), the presence of AP after endodontic treatment was associated with the quality of root canal filling. In addition, the superior number of teeth and root canals filled in the control group comparing to the diabetic group may have interfered with the assessment. 
Diabetic patients have an increased risk of experiencing tooth loss or edentulism than healthy patients. A relevant factor for tooth loss in these patients is that the most severe form of periodontal disease is associated with DM, even interfering with the patient's glycemic control (Helal et al., 2019; Preshaw et al., 2012). Although there is an association between the increased loss of endodontically treated teeth in diabetics, it is not possible to dissociate periodontal disease in these cases.

Our results also showed the association of AP in teeth with root canal filling whose restorations were unsatisfactory. The loss or inadequacy of the coronary restoration allows the re-entry of microorganisms inside the root canal, allowing reinfection after endodontic treatment. Coronary restoration must be properly performed regardless of the type of restoration that the tooth will subsequently receive, whether with composite resin or fixed prostheses (Gillen et al., 2011). Furthermore, coronary restoration has a higher influence on the success of endodontic treatment than the quality of root canal filling (Ray \& Trope, 1995).

Among the signs and symptoms associated with AP, the pain was predominant in the diabetic group. The presence of pain in diabetic patients may be related to the exacerbating periapical inflammatory reactions, mainly associated with a hyperglycemic state (Bender \& Bender, 2003). In addition, patients with diabetes may have more elevated sensitivity to neuropathic pain, such as orofacial pain (Aguiar, Ramos, \& Bichara, 2018).

The results of the present study should be interpreted with caution due to limitations related to the absence of subgroups among diabetic patients. It is known that the higher prevalence of AP reported in the literature is associated with a more severe form of diabetes, in cases when there is no glycemic control. Furthermore, it was not possible to dissociate DM from arterial hypertension, as in most cases the two conditions were simultaneously present. Patients with controlled arterial hypertension are considered healthy, thus they do not directly interfere in the presented result. Therefore, future studies evaluating the prevalence of AP according to glycemic control and taking into account the control of hypertension (if present) should be carried out.

\section{Conclusion}

Overall, this study showed an association between the presence of AP and DM in cases of teeth without endodontic treatment. There was also a significant association in the presence of pain in diabetic patients compared to healthy patients. However, healthy patients showed more cases of AP in endodontically treated teeth than diabetic patients. Unsatisfactory quality of root canal filling and coronary restoration was associated with the presence of periapical lesions.

\section{Acknowledgments}

This work was supported by the Brazilian agencies São Paulo State Research Foundation (FAPESP) [Grant numbers 2018/20887-3], and for the Coordination of the Improvement of Higher Education Personnel - CAPES (Finance code 001).

\section{References}

Abbott, P. V. (2004). Classification, diagnosis and clinical manifestations of apical periodontitis. Endodontic topics, 8(1), 36-54.

Aguiar, F. L. X. D. S., Ramos, L. F. P., \& Bichara, C. N. C. (2018). Detection of pain with neuropathic characteristics in patients with diabetes mellitus assisted in primary care units. BrJP, $1,15-20$.

Ahmed N. (2005). Advanced glycation endproducts--role in pathology of diabetic complications. Diabetes research and clinical practice, 67(1), 3-21. https://doi.org/10.1016/j.diabres.2004.09.004

American Association of Clinical Endocrinologists Board of, D., \& American College of Endocrinologists Board of, T. (2010). American Association of Clinical Endocrinologists/American College of Endocrinology statement on the use of hemoglobin A1c for the diagnosis of diabetes. Endocr Pract, 16(2), 155-156. 10.4158/EP.16.2.155

American Diabetes, A. (2013). Diagnosis and classification of diabetes mellitus. Diabetes Care, 36 Suppl 1, S67-74. 
Arya, S., Duhan, J., Tewari, S., Sangwan, P., Ghalaut, V., \& Aggarwal, S. (2017). Healing of Apical Periodontitis after Nonsurgical Treatment in Patients with Type 2 Diabetes. J Endod, 43(10), 1623-1627. 10.1016/j.joen.2017.05.013

Bender, I. B., \& Bender, A. B. (2003). Diabetes mellitus and the dental pulp. J Endod, 29(6), 383-389. 10.1097/00004770-200306000-00001

Bender, I. B., Seltzer, S., \& Freedland, J. (1963). The Relationship of Systemic Diseases to Endodontic Failures and Treatment Procedures. Oral Surg Oral Med Oral Pathol, 16, 1102-1115. 10.1016/0030-4220(63)90226-3

Britto, L. R., Katz, J., Guelmann, M., \& Heft, M. (2003). Periradicular radiographic assessment in diabetic and control individuals. Oral Surg Oral Med Oral Pathol Oral Radiol Endod, 96(4), 449-452. 10.1016/s1079-2104(03)00034-9

Cabanillas-Balsera, D., Martin-Gonzalez, J., Montero-Miralles, P., Sanchez-Dominguez, B., Jimenez-Sanchez, M. C., \& Segura-Egea, J. J. (2019). Association between diabetes and nonretention of root filled teeth: a systematic review and meta-analysis. Int Endod J, 52(3), 297-306. 10.1111/iej.13011

Correia-Sousa, J., Madureira, A. R., Carvalho, M. F., Teles, A. M., \& Pina-Vaz, I. (2015). Apical periodontitis and related risk factors: Cross-sectional study. Revista Portuguesa de Estomatologia, Medicina Dentária e Cirurgia Maxilofacial, 56(4), 226-232. https://doi.org/10.1016/j.rpemd.2015.08.004

de Morais Santos, M. P., da Silva, T. C. L., Barbosa, L. M., de Arruda, C. V. B., da Silva Batista, R. C., Negreiros, J. H. C. N., \& Laureano Filho, J. R. (2020). Associação entre periodontite apical crônica e diabetes mellitus tipo II. Research, Society and Development, 9(9), e936998002-e936998002.

DeFronzo, R. A., Ferrannini, E., Groop, L., Henry, R. R., Herman, W. H., Holst, J. J., \& Weiss, R. (2015). Type 2 diabetes mellitus. Nat Rev Dis Primers, 1, 15019. 10.1038/nrdp.2015.19

Doyle, S. L., Hodges, J. S., Pesun, I. J., Baisden, M. K., \& Bowles, W. R. (2007). Factors affecting outcomes for single-tooth implants and endodontic restorations. J Endod, 33(4), 399-402. 10.1016/j.joen.2006.12.025

Falk, H., Hugoson, A., \& Thorstensson, H. (1989). Number of teeth, prevalence of caries and periapical lesions in insulin-dependent diabetics. Scand J Dent Res, 97(3), 198-206. 10.1111/j.1600-0722.1989.tb01603.x

Gillen, B. M., Looney, S. W., Gu, L. S., Loushine, B. A., Weller, R. N., Loushine, R. J., \& Tay, F. R. (2011). Impact of the quality of coronal restoration versus the quality of root canal fillings on success of root canal treatment: a systematic review and meta-analysis. $J$ Endod, 37(7), 895-902. 10.1016/j.joen.2011.04.002

Graunaite, I., Lodiene, G., \& Maciulskiene, V. (2012). Pathogenesis of apical periodontitis: a literature review. J Oral Maxillofac Res, 2(4), e1. 10.5037/jomr.2011.2401

Helal, O., Gostemeyer, G., Krois, J., Fawzy El Sayed, K., Graetz, C., \& Schwendicke, F. (2019). Predictors for tooth loss in periodontitis patients: Systematic review and meta-analysis. J Clin Periodontol, 46(7), 699-712. 10.1111/jcpe.13118

Huumonen, S., \& Ørstavik, D. J. E. T. (2002). Radiological aspects of apical periodontitis. Endodontic Topics, 1(1), 3-25.

Ilea, A., Babtan, A. M., Bosca, B. A., Crisan, M., Petrescu, N. B., Collino, M., \& Campian, R. S. (2018). Advanced glycation end products (AGEs) in oral pathology. Arch Oral Biol, 93, 22-30. 10.1016/j.archoralbio.2018.05.013

International Diabetes Federation. (2019). IDF Diabetes Atlas (9th ed.). Brussels, Belgium.

Jakovljevic, A., \& Duncan, H. F. (2020). Diabetes Mellitus May Negatively Influence the Outcome of Conventional Nonsurgical Root Canal Treatment. J Evid Based Dent Pract, 20(3), 101467. 10.1016/j.jebdp.2020.101467

Lamster, I. B., Lalla, E., Borgnakke, W. S., \& Taylor, G. W. (2008). The relationship between oral health and diabetes mellitus. J Am Dent Assoc, 139 Suppl, 19S-24S. 10.14219/jada.archive.2008.0363

Lopez-Lopez, J., Jane-Salas, E., Estrugo-Devesa, A., Velasco-Ortega, E., Martin-Gonzalez, J., \& Segura-Egea, J. J. (2011). Periapical and endodontic status of type 2 diabetic patients in Catalonia, Spain: a cross-sectional study. J Endod, 37(5), 598-601. 10.1016/j.joen.2011.01.002

Marotta, P. S., Fontes, T. V., Armada, L., Lima, K. C., Rocas, I. N., \& Siqueira, J. F., Jr. (2012). Type 2 diabetes mellitus and the prevalence of apical periodontitis and endodontic treatment in an adult Brazilian population. J Endod, 38(3), 297-300. 10.1016/j.joen.2011.11.001

Orstavik, D., Kerekes, K., \& Eriksen, H. M. (1986). The periapical index: a scoring system for radiographic assessment of apical periodontitis. Endod Dent Traumatol, 2(1), 20-34. 10.1111/j.1600-9657.1986.tb00119.x

Preshaw, P. M., Alba, A. L., Herrera, D., Jepsen, S., Konstantinidis, A., Makrilakis, K., \& Taylor, R. (2012). Periodontitis and diabetes: a two-way relationship. Diabetologia, 55(1), 21-31. 10.1007/s00125-011-2342-y

Ray, H. A., \& Trope, M. (1995). Periapical status of endodontically treated teeth in relation to the technical quality of the root filling and the coronal restoration. Int Endod J, 28(1), 12-18.

Rudranaik, S., Nayak, M., \& Babshet, M. (2016). Periapical healing outcome following single visit endodontic treatment in patients with type 2 diabetes mellitus. J Clin Exp Dent, 8(5), e498-e504. 10.4317/jced.52859

Segura-Egea, J. J., Jimenez-Pinzon, A., Rios-Santos, J. V., Velasco-Ortega, E., Cisneros-Cabello, R., \& Poyato-Ferrera, M. (2005). High prevalence of apical periodontitis amongst type 2 diabetic patients. Int Endod J, 38(8), 564-569. 10.1111/j.1365-2591.2005.00996.x

Smadi, L. (2017). Apical Periodontitis and Endodontic Treatment in Patients with Type II Diabetes Mellitus: Comparative Cross-sectional Survey. J Contemp Dent Pract, 18(5), 358-362. 10.5005/jp-journals-10024-2046 
Research, Society and Development, v. 10, n. 12, e142101220135, 2021

(CC BY 4.0) | ISSN 2525-3409 | DOI: http://dx.doi.org/10.33448/rsd-v10i12.20135

Ugur Aydin, Z., Ocak, M. G., Bayrak, S., Goller Bulut, D., \& Orhan, K. (2021). The effect of type 2 diabetes mellitus on changes in the fractal dimension of periapical lesion in teeth after root canal treatment: a fractal analysis study. Int Endod J, 54(2), 181-189. 10.1111/iej.13409

Zimmet, P., Alberti, K. G., Magliano, D. J., \& Bennett, P. H. (2016). Diabetes mellitus statistics on prevalence and mortality: facts and fallacies. Nat Rev Endocrinol, 12(10), 616-622. 10.1038/nrendo.2016.105 